\title{
The bat fauna of the Mpem and Djim National Park, Cameroon (Mammalia Chiroptera)
}

\author{
Atagana Patrick Jules '*, Bakwo fils Eric Moise', Mbeng Donatus Waghiiwimbom', Tsague Kenfack Joseph \\ Aimél \& Kekeunou Sévilor ${ }^{2}$ \\ ${ }^{1}$ Department of Biological Sciences, Faculty of Sciences, University of Maroua, P.O. Box 814, Maroua, Cameroon \\ ${ }^{2}$ Laboratory of Zoology, Department of Biology and Animal Physiology, Faculty of Sciences, University of Yaounde I, P.O Box \\ 812, Yaoundé, Cameroon \\ *Corresponding author, e-mail: apatrickjules@yahoo.fr
}

ABSTRACT

\begin{abstract}
The present study reports on a bat inventory in the Mpem and Djim National Park (Mammalia Chiroptera), in the Centre region of Cameroon. Fourteen sites were surveyed from July 2016 to January 2017. A total of 166 bats were captured. This included 14 species, 11 genera, and five families. All species are globally ranked as "Least Concern" except Glauconycteris egeria, a Data Deficient species by the International Union for Conservation of Nature Red List of threatened species. Micropteropus pusillus and Lissonycteris angolensis were recorded from previous surveys in all the ten regions of the country encompassing five agroecological zones. Out of the fourteen species, ten species are known to occur both in the forest and the savanna, while four are reported only from the forest. This study provides baseline data about Chiropteran fauna of this protected area.
\end{abstract}

KEY WORDS

Cameroon; Chiropteran; Inventory; Mpem and Djim Park.

Received 26.05.2018; accepted 11.08.2018; printed 30.09.2018; published online 05.10.2018

\section{INTRODUCTION}

The average annual rate of deforestation in Cameroon is among the highest in Central Africa (FAO, 1997). Indeed, Ndoye \& Kaimowitz (1998) estimated this deforestation at a rate of 80,000 to 200,000 hectares per year. However, it is clear that tropical forests are the largest reservoir of biodiversity (Fittkan, 1997). Each year, the destruction of millions of hectares of tropical forests involves the disappearance of thousands of plant and animal species, of which most was never indexed (Dubois, 2005). Forests in Cameroon have one of the richest and most diverse fauna in Sub-Saharan Africa (Bikié et al., 2000). They contain several classes of vertebrates, including amphibians (190 species), reptiles (183 species), birds (916 species), and mammals (409 species) (Verbelen, 1999).

Although the Mammal's fauna in Cameroon has been the subject of several studies, bats remain one of the most neglected and poorly studied faunal groups (Bakwo Fils, 2010), despite their major ecological role (Reis \& Guillaumet, 1983). Indeed, the valuable ecological services rendered by these animals are ignored by the populations and even by the authorities in charge of managing biodiversity (Bakwo Fils, 2010). Bats, with over 1300 described species, constitute the second most diverse group of mammals after rodents, among the 5000 species of mammals described to date (BannetGarcia, 2003). They are unique among mammals as a result of true flight capacity, echolocation abil- 
ity, and communal life that could reach several thousands in one assemblage. These poorly known and threatened animals are not included in conservation and wildlife management programs in tropical ecosystems despite their ecological and economic importance (Bannet-Garcia, 2003; Bakwo Fils, 2009a, 2010). This explains the lack of scientific information about bats in Cameroon, which hinders development of effective conservation strategies for these animals.

This preliminary work gives baseline data on the diversity of bats in the Mpem and Djim National Park in the Centre region of Cameroon.

\section{MATERIAL AND METHODS}

\section{Study area}

The Mpem and Djim National Park is situated in the Centre region of Cameroon (Fig. 1). The climate is a Classic Guinean type with four seasons: a long dry season (from mid-November to midMarch); a short rainy season (mid-March to end of June); a short dry season (from July to August) and a long rainy season (from September to mid-November) (Santoir \& Bobda, 1995). Precipitations range between 1800 and $2000 \mathrm{~mm}^{3}$ per year and the temperatures are found between $22^{\circ}$ and $29^{\circ} \mathrm{C}$ (Santoir \& Bobda, 1995). The Mpem and Djim National Park is a vast natural space of 97,480 hectares bounded by the loop which form the Mpem and Djim rivers, two long rivers hosting a rich and diversified aquatic fauna. Recent studies have revealed that the Mpem and Djim Park harbours 76 species of mammals. Among these, rare species (panthers, chimpanzees, hippopotamus, and elephants) are threatened to decline and they even at risk of extinction (MINFOF, 2011). The fact that the park is located in a transition zone between the forest and the savannah gives this protected area a special floristic and faunal character. In the savannah zone there is abundance of Chromolaena odorata (L.) R.M. King \& H. Rob. (Bokassa Grass) and Imperata cylindrica (L.) Raeusch. in the herbaceous layer, while the tree layer is dominated by Albizzia sp., Lophira sp. and Ochroma africanus. In the forest, the following species of trees are dominant: Piptadeniastrum africanum (Hook. f.) Brenan, Milicia excelsa (Welw.) C.C. Berg, Pterocarpus soyauxii Taub., Nauclea diderrichii (De Wild. \& T.
Durand) Merrill, Alstonia boonei De Wild., Mansonia altissima (A. Chev.) A. Chev., Garcinia kola Heckel, Entandrophragma utile C. DC., E. candollei Harms, Lovoa trichilioides Harms.

\section{Bats capture}

In the course of our work, we carried out captures in 14 sites within the forest and the savannah ecosystems (Table 1). Capture sites were chosen based on the potential flight trajectories of bats (water, caves, and tree cavities). The captures were made using nylon mist nets of $12 \times 2.60 \mathrm{~m}$ and $6 \times 2.60 \mathrm{~m}$ with $16 \mathrm{~mm}$ mesh and four pockets. These nets were installed for 20 nonconsecutive nights from June 22, 2016 to January 20, 2017 (Table 1). Mist nets were attached to $4 \mathrm{~m}$-long poles and stretched across potential trajectories of bats, such as water bodies, forest openings, cave openings, and tree hollows between $6 \mathrm{pm}$ and $12 \mathrm{pm}$ to maintain uniform sampling efforts across sites. Mist nets were monitored continuously every 15 minutes. Using gloves, the individuals caught in the mist nets were carefully removed to avoid trauma to the animals.

\section{Identification}

After capture, each individual caught was weighed using a scale balance (Pesola balance, nearest $0.5 \mathrm{~g}$ ), measured using a vernier caliper following standard techniques (Lindan et al., 1997), and sexed (Table 3). Presence of tragus (for insectivorous bats), date of capture, and geographic position of capture sites were also recorded. Morphological data from each captured bat is used for identification using the keys of Rosevear (1965), Hayman \& Hill (1971), Patterson \& Webala (2012), and Happold \& Happold (2013). After identification, all individual were released.

Literature review was carried out for each species caught in order to identify the different localities (Table 4) in which they have been previously captured in the country. The African Chiroptera Report (ACR, 2017) was used in order to have some indications on the distribution in Cameroon of the species caught at the park. GPS coordinates of the localities of occurrence retrieved from the database and data from this study enabled us to realize new maps of the distribution of the captured species in Cameroon using the software QGIS 2.4.0 Chugiak. 


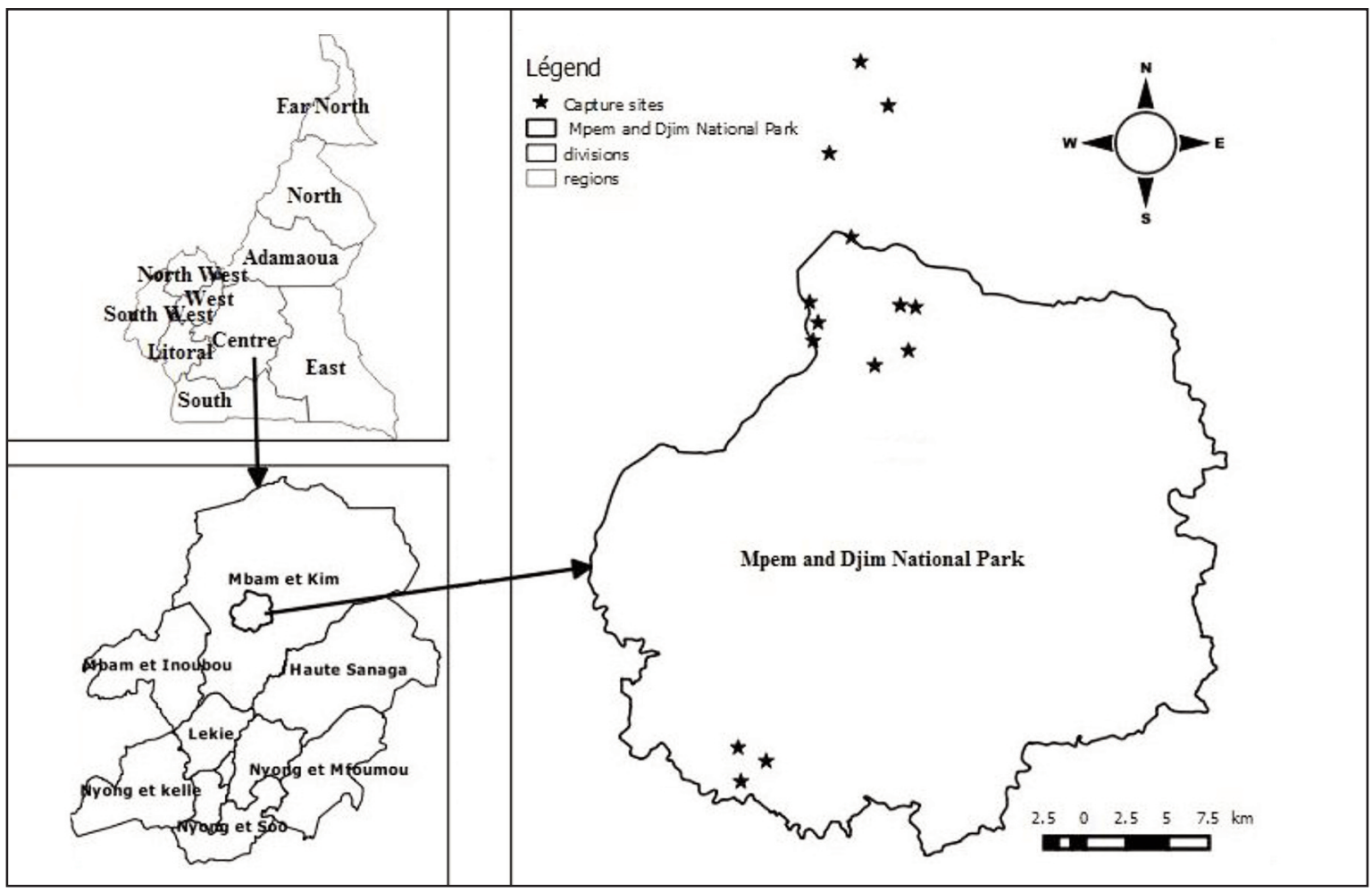

Figure 1. Map of the Mpem and Djim National Park, Cameroon.

\begin{tabular}{|c|c|c|c|c|c|c|}
\hline SITES & Longitudes & Latitudes & Altitudes & nature of the site & Date & $\begin{array}{c}\text { Length and } \\
\text { number of net }\end{array}$ \\
\hline SITE 1 & $\mathrm{~N} 05.03341$ & E 011.62518 & $507 \mathrm{~m}$ & forest-savannah & 22 and $23 / 07 / 16$ & $\begin{array}{c}12 \mathrm{~m}(2) \text { and } \\
6 \mathrm{~m}(4)\end{array}$ \\
\hline SITE 2 & N 05.04452 & E011.63909 & $542 \mathrm{~m}$ & forest & 24 and $25 / 07 / 16$ & $\begin{array}{l}12 \mathrm{~m}(2) \text { and } \\
6 \mathrm{~m}(4)\end{array}$ \\
\hline SITE 3 & N 05.05204 & E011.62371 & $582 \mathrm{~m}$ & forest (tree) & 26 and $27 / 07 / 16$ & $\begin{array}{c}12 \mathrm{~m}(3) \text { and } \\
6 \mathrm{~m}(5)\end{array}$ \\
\hline SITE 4 & N05.33230 & E011.68691 & $654 \mathrm{~m}$ & savannah & 28 and $29 / 07 / 16$ & $\begin{array}{c}12 \mathrm{~m}(3) \text { and } \\
6 \mathrm{~m}(5)\end{array}$ \\
\hline SITE 5 & N5.26985 & E11.71796 & $630 \mathrm{~m}$ & forest & $30 / 07 / 2016$ & $\begin{array}{c}12 \mathrm{~m}(3) \text { and } \\
6 \mathrm{~m}(5)\end{array}$ \\
\hline SITE 6 & N5.26171 & E11.69945 & $657 \mathrm{~m}$ & forest & $20 / 11 / 2016$ & $\begin{array}{c}12 \mathrm{~m}(2) \text { and } \\
6 \mathrm{~m}(4)\end{array}$ \\
\hline SITE 7 & N5.27546 & E11.66578 & $607 \mathrm{~m}$ & forest & $21 / 11 / 2016$ & $\begin{array}{l}12 \mathrm{~m}(3) \text { and } \\
6 \mathrm{~m}(5)\end{array}$ \\
\hline SITE 8 & N5.28539 & E11.66853 & $631 \mathrm{~m}$ & $\begin{array}{l}\text { savannah } \\
\text { (swamp) }\end{array}$ & $22 / 11 / 2016$ & $\begin{array}{c}12 \mathrm{~m}(3) \text { and } \\
6 \mathrm{~m}(5)\end{array}$ \\
\hline SITE 9 & N5.29362 & E11.72195 & $674 \mathrm{~m}$ & forest & $23 / 11 / 2016$ & $\begin{array}{l}12 \mathrm{~m}(3) \text { and } \\
6 \mathrm{~m}(5)\end{array}$ \\
\hline SITE 10 & N5.29473 & E11.71357 & $632 \mathrm{~m}$ & forest & $26 / 11 / 2016$ & $\begin{array}{l}12 \mathrm{~m}(3) \text { and } \\
6 \mathrm{~m}(5)\end{array}$ \\
\hline SITE 11 & N5.29668 & E11.66396 & $639 \mathrm{~m}$ & forest & $17 / 01 / 2017$ & $\begin{array}{l}12 \mathrm{~m}(3) \text { and } \\
6 \mathrm{~m}(5)\end{array}$ \\
\hline SITE 12 & N5.37846 & E11.67512 & $617 \mathrm{~m}$ & forest (tree) & $18 / 01 / 2017$ & $\begin{array}{c}12 \mathrm{~m}(3) \text { and } \\
6 \mathrm{~m}(5)\end{array}$ \\
\hline SITE 13 & N5.40448 & E11.70747 & $646 \mathrm{~m}$ & savannah (cave) & $19 / 01 / 2017$ & $\begin{array}{c}12 \mathrm{~m}(3) \text { and } \\
6 \mathrm{~m}(5)\end{array}$ \\
\hline SITE 14 & N5.42876 & E11.69236 & $792 \mathrm{~m}$ & forest (cave) & $20 / 01 / 2017$ & $\begin{array}{l}12 \mathrm{~m}(1) \text { and } \\
6 \mathrm{~m}(4)\end{array}$ \\
\hline
\end{tabular}

Table 1. Geographical coordinates description of capture sites, date of capture, and number of nets in the Mpem and Djim National Park, Cameroon. 


\section{RESULTS}

In 20 nights, we captured 166 bats belonging to 14 species, 10 genera, and 5 families. This corresponds to a capture success of 0.69 individuals per night and a capture effort of 239.2 nets per night (Table 2). The family Pteropodidae was the richest in species richness (6 species), followed by Hipposideridae and Vespertilionidae with 3 species each. Rhinolophidae and Nycteridae were monospecific (Table 2).

\section{Species account}

\section{Fruit bats}

\section{Casinycteris argynnis Thomas, 1910}

Only one male individual of this species was captured in the north of the park (forest area) along a river. This species is listed as Least Concern (LC) in the IUCN Red List and its population trend is unknown (Webala et al., 2016). This forest species was previously recorded in Cameroon in Mefo (Peret \& Aellen, 1956), Bityé, Mang, Meyo Nkoulou, Mefo (Bergmans, 1990), South Cameroon (Happold \& Happold, 2013), Ambam, Meyo, Nkoulou (ACR, 2017) (Fig. 2).

\section{Epomops franqueti Tomes, 1860}

Six individuals, including 3 females and 3 males of this species, were captured at sites 2, 10 (secondary forest), and 11 (primary forest). This species is listed as LC in the IUCN Red List and its population trend is unknown (Kityo \& Nalikka, 2016). This forest species, captured in the north and south of the park, was previously recorded in Cameroon in Aqua Town, Mungo (Peters, 1876), Kribi (Matschie, 1891), Barombi, Victoria (Matschie, 1895), Itoki (Sjostedt, 1897a \& b), Yaounde (Matschie, 1899), Bityé, Bipindi small Batanga (Andersen, 1912), Ndikinimeki, Konn (Aellen, 1952), Ambam, Foulassi, Ngam (Peret \& Aellen, 1956), Yaounde (Haiduk et al., 1981), Bamenda, Batanga, Batouri, Bimbia, Bipindi, Bitye, Bota, Buea, Dikume balue, Douala, Ekona, Ekundu, Eseka, Essossong, Foulassi, Garoua, klein, Kuwait, Mumbai, Mbudu, Mengue, Muqiu, Yoko, Idenau, Ikiliwindi, Isobi, Itoki, Konn, Lake Barombi, Mabeta, Mbo, Meanja,
Mawutu, Metet, Mukonje, Ndikinimeki, Ngam, Ngaoundere, Tiko (Bergmans, 1988), Kilum-Ijim (Maisel et al., 2001), and Dja Reserve (Bakwo Fils, 2009b) (Fig. 3).

\section{Micropteropus pusillus Peters, 1868}

This species is widespread in Cameroon (Fig. 4). Seventeen individuals (10 males and 7 females) were recorded in the north and south of the park. In the north, it was captured beside a river (forest area) and in the swampy savannah. In the south it was caught in the forest-savannah transition zone. This species is listed as LC in the IUCN Red List and its population trend is unknown (Bakwo Fils \& Kaleme, 2016a). This species was previously recorded in Cameroon in Yaounde (Matschie, 1895), Tinta (Sanderson, 1940), Ngaoundere (Haiduk et al., 1981; Muller et al., 1981), Banyo (Huterrer \& Joger, 1982), Jauro Massali (Huterrer et al., 1992), Bafut, Banyo, Bota, Buea, Boukma, Campo, Djohong, Ekona, Eseka, Koutaba, Kribi, Galim, Koza, Kombetiko, Kounden, Lekoung, Lolabe, Maroua,Mbakaou, Mbokaon, Mbouda river, Meanja, Metchum, Meiganga, Mount Cameroon, Mount Manengouba, Molyko, Mokolo, Mpundu, Nachtigal, Ngaoundere, Nkolbisson, Ntui, Obala, Mayo-Darlé, Tibati, Poli, Tombel, Wakwa, Yagoua, Yaounde, Yoko, (ACR, 2017), Maga, Mokolo (Bakwo Fils, personal data).

\section{Lissonycteris angolensis Bocage, 1898}

A single male and a single female were mist nested at a drinking site in the forest area of the Park. This species is listed as LC in the IUCN Red List and its population trend is unknown (Bergmans et al., 2017). This forest species was previously recorded in Buea (Matchie, 1891), Bibundi, Bonge, Ndiang, (Sjostedt, 1897a; 1897b), Bimbia, Tombel (Eisentraut, 1942), Eseka (Haiduk et al., 1981), Ngaoundere (Muller et al., 1981), Dja Reserve (Bakwo Fils, 2009a). Specimens currently kept in museums were collected in Bafut, Banyo, Boukma, Buea, Campo, Djohong, Eseka, Galim, Gwofong, Lolabe, Mayo Darle, Kombe, Kounden, Koutaba, Koza, Kribi, Lekoung, Mbakaou, Mbokoan, Meanja, Meiganga, Moliko River, Mount Manegouba, Mokolo, Mpundu, Ngaoundere, Ntui, Nachtigal, Obala, Poli, Tibati, 
Tiko, Touroua, Tote, Wakwa, Yagoua, Yaounde, Yoko (ACR, 2017) (Fig. 5).

\section{Myonycteris torquata Dobson, 1878}

The single male individual was captured in a marshy area, beside a stream within the forest. This forest and savannah species (Fig. 6) is listed as LC in the IUCN Red List and its population trend is unknown (Bakwo Fils \& Kaleme, 2016b). This forest species was previously recorded in Ngaoundere (Haiduk et al., 1981), the Natural Reserve of Campo (Cosson, 1995), and Dja reserve (Bakwo Fils, 2009a). Specimens currently kept in museums were collected in Aboulou, Belabo, Bertoua, Bityé, Bota, Buea, Campo, Dimako, Eseka, Ebolowa, Kanyol, Koutaba, Kumba, Lake Barombi, Lake Tissongo, Lolodorf, Lomié, Mesea, Meyo, Mey Joss, Nkoulou, Nguilili, Ngoume, Ntui, Ngobilo, Yaoundé (ACR, 2017).

Rousettus aegyptiacus Geoffroy St.-Hilaire, 1810

This species is widely distributed in the western part of Cameroon (Fig. 7) and it is recorded to come from natural forest gaps in the northern part of the park. Two individuals were captured at drinking sites (rivers) (sites 6 and 9). In the northern periphery of the park, six other individuals were caught in a cave (site 14) that contained more than 300 individuals. All the adult females carried a young as they escaped from the cave. This species is listed as LC in the IUCN Red List and its population trend is unknown (Korine, 2016). This forest species was previously recorded in Buea (Sanborn, 1936), Mamfe (Sanderson, 1940), Kilum-Ijim forest (Maisel et al., 2001), Dja reserve (Bakwo Fils, 2009b). Specimens currently kept in museums were collected in Bafut, Bamenda, Bipindi, Bota, Boteke Village, Campo, CDC Banana Plantation, Dokoa, Ekona, Great Soppo, Isobi, Lake Barombi, Kribi, Lododorf, Mount Cameroon, Mueli, Mukono, Ngoume, Sakbayeme, Tiko, Toura, Tombel, Yaounde (ACR, 2017).

\section{Insectivorous bats}

\section{Rhinolophus alcyone Temminck, 1853}

This species was recorded in the northern part of the park and it is less widely distributed in
Cameroon (Fig. 8). The single female individual was captured across a river in the forest. This species is listed as LC in the IUCN Red List and its population trend is unknown (Monadjem et al., 2017a). This forest species was previously recorded from Mamfe (Sanderson, 1940), Nyasosso, Mount Kupe, Wildi cave, Buena, Nkoetye (Perret \& Aellen, 1956), Mount Cameroon (Eisentraut, 1964). Specimens currently kept in museums were collected in Boteke Village, Bokwango, Bova Village, Eseka, Gwando, Meyo, Moloko, Moungo, Mpundu, Muyuka, Nkoetye, Nkoulou, Soppo, Soumo River, Soppo (ACR, 2017) (Fig. 8).

\section{Hipposideros cyclops Temminck, 1853}

This species is widely distributed in the southern part of the country (Fig. 9). Three individuals ( 1 female and 2 males) were captured in the northern part of the park beside a river (site 6) and in a dead tree trunk (site 12). This species is listed as LC in the IUCN Red List and its population trend is unknown (Monadjem et al., 2017b). This forest and savannah species was previously recorded on Mount Cameroon (Dobson, 1878), Buea (Matschie, 1891), Kita (Sjostedt, 1897b), Efoulen (Allen, 1922), Besongabang, Okoiyong, Eshobi, Bashauo, Atolo, Tinta, Bitye (Sanderson, 1940), MubengeIsongo (Eisentraut, 1942), Kribi, Akak (Aellen, 1952), Dja Reserve (Bakwo Fils, 2009a), Camp II, Mount Kupe (Hill, 1968), Ngam, Meyo, Ambam (Perret \& Aellen, 1956). Specimens currently kept in museums were collected in Bebai, Bele, Bertoua, Bipindi, Bokwango, Buea, Bunduma Village, Ebolowa, Efulen, Eseka, Isongo, Kribi, Lake Muyuka, Lombe, Mengueme, Metet, Meyo, Mieri, Muyuka, Nkoulou, Ngoume, Ndjole, Olounou, Sangmelima, Sakbayeme, Tisongo, and Zulabot II (ACR, 2017) .

\section{Hipposideros fuliginosus Temminck, 1853}

This species is found in both the forest and the savannah in the northern part of the park. Seventeen individuals ( 9 females and 8 males) were caught at a drinking site (small stream) in the forest (sites 6 and 9) and in a savannah cave (site 13) that contained more than 200 individuals. This species is listed as LC in the IUCN Red List and its population trend is unknown (Monadjem et al., 2017c). 
This species was previously recorded in the Mungo (Peters, 1876), Victoria (Sjostedt 1897b), Sakbayeme (Allen, 1921), Ndikiniméki (Aellen, 1952), Dja Reserve (Bakwo Fils, 2009a). Specimens currently kept in museums were collected in Mamfé, Kumba, and Kribi (ACR, 2017) (Fig. 10).

\section{Hipposideros ruber Noack, 1893}

This species was caught in the north and south of the forest as well as in the northern periphery of the park. Ninety-seven individuals were caught in 5 sites $(2,3,5,9$, and 6$)$, all located in the forest. It is the most abundant and was caught in a living tree cavity and along a river. This species is listed as LC in the IUCN Red List and its population trend is un- known (Monadjem et al., 2017d). This forest and savannah (Fig. 11) species was previously recorded in Jauro Massali (Hutterer et al., 1992), Kilum-Ijim (Maisel et al., 2001), Dja Reserve (Bakwo Fils, 2009a), Makot (Bakwo Fils, personal data). Specimens currently kept in museums were collected in Bertoua, Bipindi, Bitye, Buea, Campo, Ebolowa, Efulen, Eseka, Kribi, Kumba, Lake Barombi, Lomie, Mamfe, Mbalmayo, Mount Cameroon, Nanga Eboko, Poli, Mieri, Sakbayeme, Sangmelima, and Telo (ACR, 2017).

\section{Nycteris grandis Peters, 1865}

This species was caught in a swampy area beside a river in the forest (site 7) in the northern part of

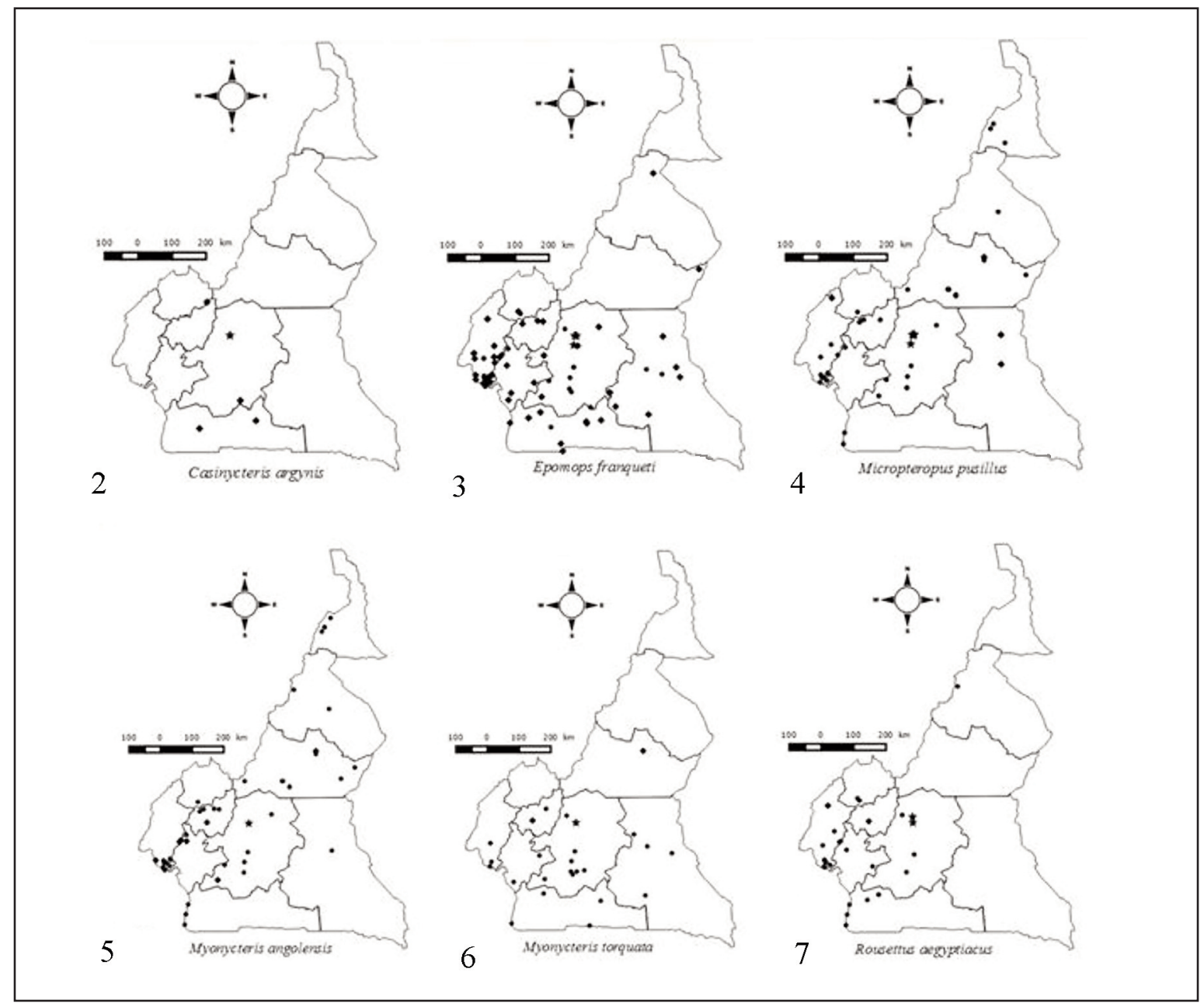

Figures 2-7. Distribution maps of the different species caught in the Mpem and Djim N. P. in Cameroon. Star = capture point in the park, dot $=$ capture points of the specimens in the museum and other capture points reported in Cameroon). Fig. 2: C. argynis. Fig. 3: E. franqueti. Fig. 4: M. pusillus. Fig. 5: M. angolensis. Fig. 6: M. torquata. Fig. 7: R. aegyptiacus. 
the park. It is listed as LC in the IUCN Red List and its population trend is unknown (Monadjem et al., 2017e). This forest and savannah (Fig. 12) species was recorded in Bitye (Andersen, 1912), MubengueIsongo (Eisentraut, 1942), Myntyaminyumin, Ngam (Perret \& Aellen, 1956), Dja Reserve (Bakwo Fils, 2009a). Specimens currently kept in museums were collected in Bitye, Bipindi, Bonge, Douala, Edea Game Reserve, Kumba, Kribi, Lumbindu, Malende Swamp Area, Myntjaminyumin, Mount Cameroon, Ngam, Ndjole, Njombo River, Sangmelima, and Tisongo (ACR, 2017).

Neoromicia tenuipinnis Peters, 1872

This species is found in the forest, in the northern part of the park. Two male individuals of this forest and savannah species were caught at the drinking sites. Neoromicia tenuipinnis is listed as LC in the IUCN Red List (Monadjem \& Fahr, 2017a). It was previously recorded in Ambam, Yaounde (Mc Bee et al., 1987), Isongo, Debundscha, Bota (Eisentraut, 1942). Specimens currently kept in museums were collected in Ambam, Bitye, Bota, Boteke Village, Isongo, Kumba, Mawutu, Yaounde, Meanja, Muyuka, Ntui, and Obala (ACR, 2017) (Fig. 13).

Glauconycteris egeria Thomas, 1913

The single male individual of this species was caught in the southern part of park in the forest be-

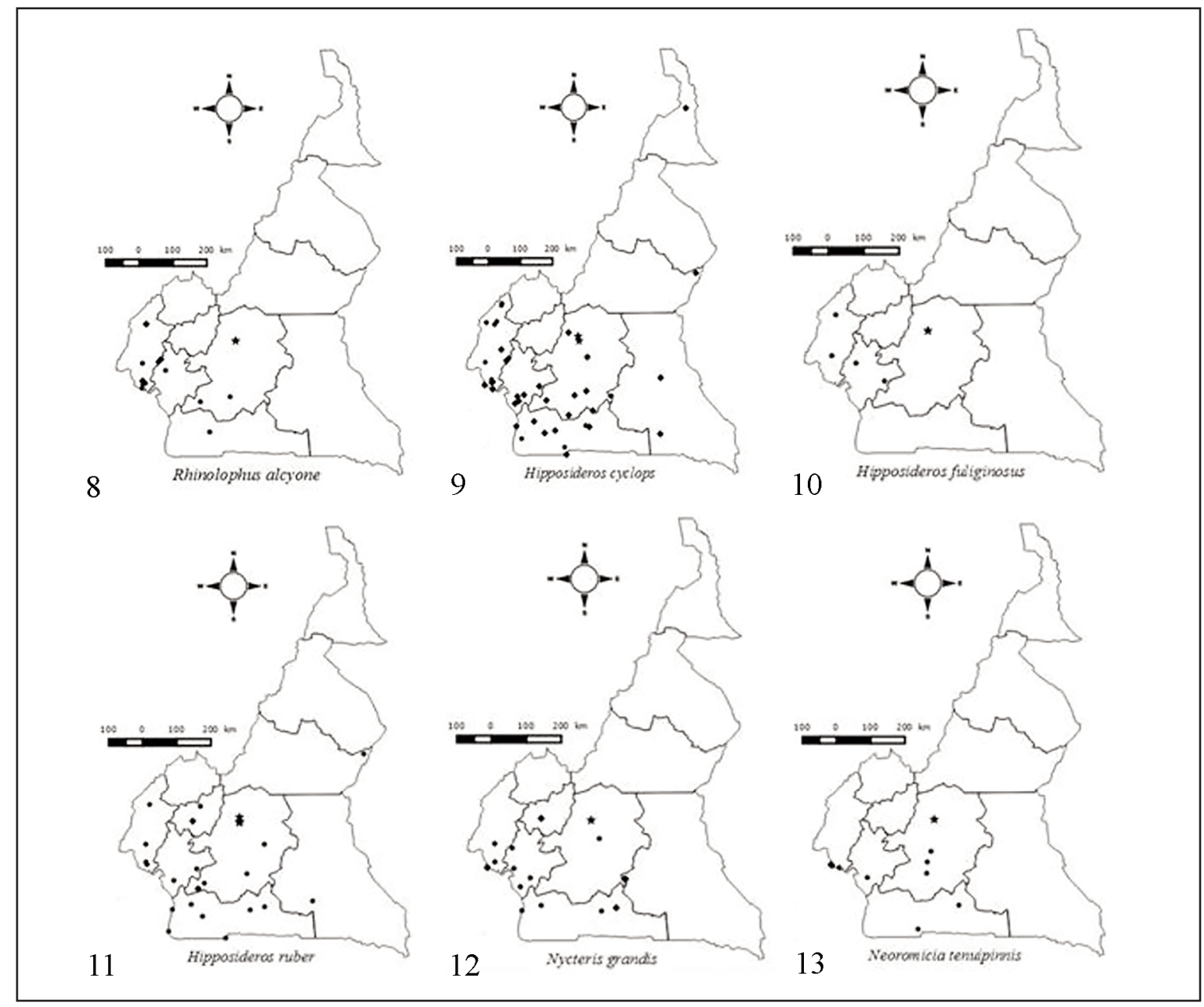

Figures 8-13. Distribution maps of the different species caught in the Mpem and Djim N. P. in Cameroon. Star = capture point in the park, dot $=$ capture points of the specimens in the museum and other capture points reported in Cameroon). Fig. 8: R. alcyone. Fig. 9: H. cyclops. Fig. 10: H. fuliginosus. Fig. 11: H. ruber. Fig. 12: N. grandis. Fig. 13: N. tenuipinnis. 
side a river. It is listed as DD in the IUCN Red List and its population trend is unknown (Jacobs et al., 2008). This forest species was previously recorded in Bibundi and Buea (ACR, 2017) (Fig. 14).

\section{Pipistrellus nanulus Thomas, 1904}

This species was caught in the northern part of park, in the forest and savannah. Nine male individuals were captured beside a river in the forest (site 6) and in the savannah (site 4). Pipistrellus nanulus is listed as LC in the IUCN Red List (Monadjem \& Fahr, 2017b). The distribution map (Fig. 15) shows that $P$. nanulus is a forest and savannah species. Van

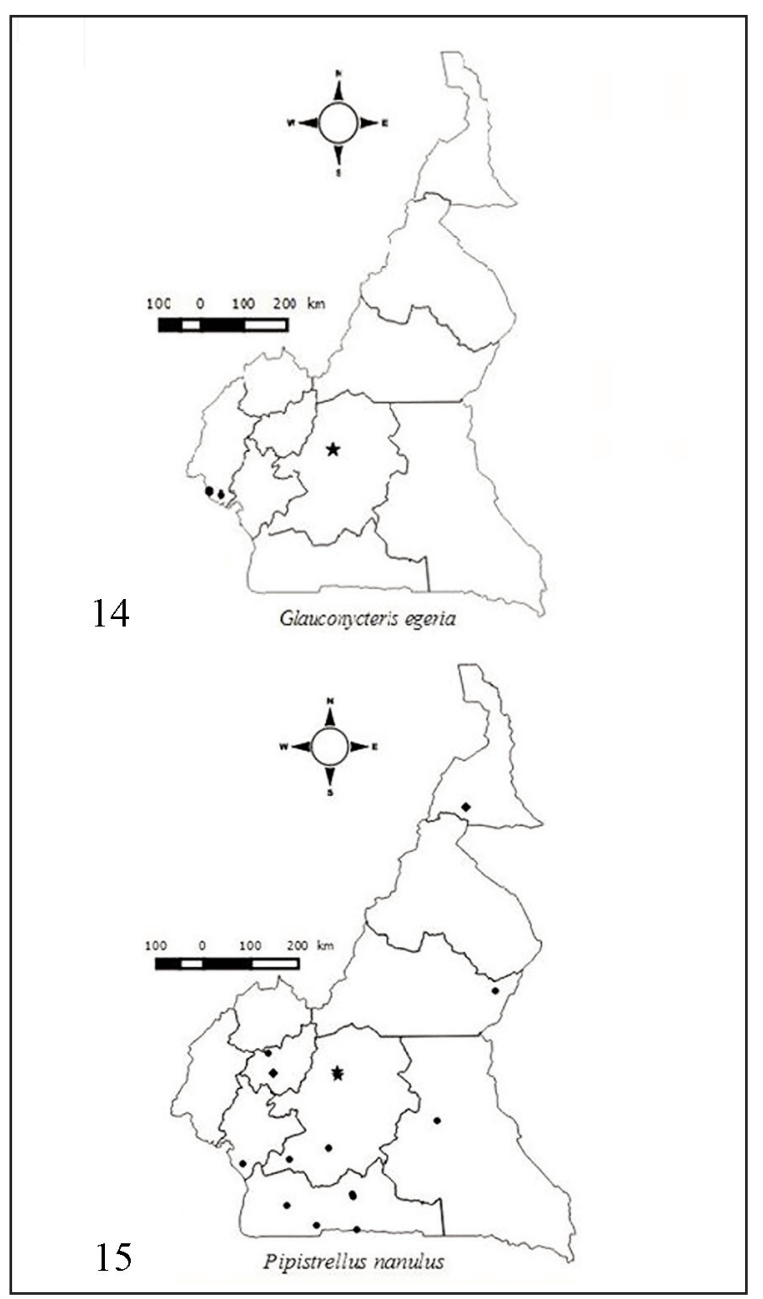

Figures 14, 15. Distribution maps of the different species caught in the Mpem and Djim N.P. in Cameroon. Star = capture point in the park, dot = capture points of the specimens in the museum and other capture points reported in Cameroon). Fig. 14: G. egeria. Fig. 15: P. nanulus.
Cakenberghe \& Happold (2013) also suggest that this species seems to prefer both forest and savannah zones as well as boundaries between the two. This ubiquitous species was previously recorded in Efulen (Rosevear, 1965), Dja Reserve (Bakwo Fils, 2009b), and Maroua (Aaron Manga, 2012; Bakwo Fils et al., 2014). Specimens currently kept in museums were collected in Aboulou, Ambam, Dimako, Eseka, Foulassi, Galim, Njombo River, Lake Tissongo, Sangmelima, and Yaounde (ACR, 2017).

\section{DISCUSSION}

Bats constitute one of the most ecologically diverse groups of vertebrates of the Mpem and Djim National Park. These animals play an important role in the functioning of the ecosystem. Insectivorous bats regulate insect populations, of which some are agricultural pests. Fruit bats disperse seeds and help maintain forest diversity (Fahr et al., 2002). This function suggests the important role bats play and their absence would impoverish the ecosystems of which they are a part of. This ecological importance may likely explain the spread of these species on the whole territory, characterized by several biogeographical zones.

The bat community of this park harbours species which rely on caves ( $R$. aegyptiacus and $H$. fuliginosus) as well as holes in trees (H. cyclops and $H$. ruber). Several favourable habitats exist for bats at the Mpem and Djim National Park. However, these habitats are threatened by the ineffective management of the park and thus favouring human action which may be harmful to the bats. These anthropic actions include bush fire caused by herdsmen, deforestation for the plantation of cocoa, etc. With the exception of $G$. egeria, which is DD in the IUCN Red List, all species captured at the study site are Least Concern in the IUCN Red List. These anthropic activities may endanger the conservation of bat species composition at the Mpem and Djim National Park Community.

Most of the captured species at the park are forest species, except M. pusillus and L. angolensis, which are cosmopolitan in Cameroon. They have been recorded in the ten administrative regions of the country. Thus, they are species of the south tropical forest, of the humid savannah in the Centre, and of the dry savannah in the Far North. It is interesting 


\begin{tabular}{|c|c|c|c|c|c|c|c|c|c|c|c|c|c|c|c|}
\hline \multicolumn{15}{|c|}{ Numbers of individuals per study site } & \multirow{2}{*}{$\begin{array}{c}\text { Total } \\
14\end{array}$} \\
\hline Species & \begin{tabular}{|c|} 
site \\
1
\end{tabular} & \begin{tabular}{|c|} 
site \\
2
\end{tabular} & \begin{tabular}{|c|} 
site \\
$\mathbf{3}$
\end{tabular} & \begin{tabular}{|c|} 
site \\
4
\end{tabular} & \begin{tabular}{|c|} 
site \\
$\mathbf{5}$
\end{tabular} & $\begin{array}{c}\text { site } \\
6\end{array}$ & \begin{tabular}{|c|} 
site \\
7 \\
\end{tabular} & \begin{tabular}{|c|} 
site \\
8 \\
\end{tabular} & \begin{tabular}{|c|} 
site \\
9
\end{tabular} & \begin{tabular}{|c|} 
site \\
10 \\
\end{tabular} & \begin{tabular}{|c|} 
site \\
11 \\
\end{tabular} & \begin{tabular}{|c|} 
site \\
12 \\
\end{tabular} & \begin{tabular}{|l|} 
site \\
13 \\
\end{tabular} & \begin{tabular}{|l|} 
site \\
14
\end{tabular} & \\
\hline \multicolumn{16}{|c|}{ Fruit bats } \\
\hline Casinycteris argynnis & 0 & 0 & 0 & 0 & 0 & 0 & 0 & 0 & 0 & 0 & 1 & 0 & 0 & 0 & 1 \\
\hline Epomops franqueti & 0 & 1 & 0 & 0 & 0 & 0 & 0 & 0 & 0 & 1 & 4 & 0 & 0 & 0 & 6 \\
\hline Micropteropus pusillus & 7 & 0 & 0 & 0 & 0 & 3 & 0 & 4 & 3 & 0 & 0 & 0 & 0 & 0 & 17 \\
\hline Myonycteris angolensis & 0 & 0 & 0 & 0 & 0 & 0 & 2 & 0 & 0 & 0 & 0 & 0 & 0 & 0 & 2 \\
\hline Myonycteris torquata & 0 & 0 & 0 & 0 & 0 & 0 & 1 & 0 & 0 & 0 & 0 & 0 & 0 & 0 & 1 \\
\hline Roussettus aegyptiacus & 0 & 0 & 0 & 0 & 0 & 1 & 0 & 0 & 1 & 0 & 0 & 0 & 0 & 6 & 8 \\
\hline \multicolumn{16}{|c|}{ Insectivorous bats } \\
\hline Rhinolophus alcyone & 0 & 0 & 0 & 0 & 0 & 0 & 0 & 0 & 1 & 0 & 0 & 0 & 0 & 0 & 1 \\
\hline Hipposideros cyclops & 0 & 0 & 0 & 0 & 0 & 2 & 0 & 0 & 0 & 0 & 0 & 0 & 0 & 0 & 3 \\
\hline Hipposideros ruber & 0 & 7 & 82 & 0 & 1 & 0 & 0 & 0 & 1 & 0 & 0 & 0 & 6 & 0 & 97 \\
\hline Hipposideros fuliginosus & 0 & 0 & 0 & 0 & 0 & 1 & 0 & 0 & 1 & 0 & 0 & 0 & 15 & 0 & 17 \\
\hline Nycteris grandis & 0 & 0 & 0 & 0 & 0 & 0 & 1 & 0 & 0 & 0 & 0 & 0 & 0 & 0 & 1 \\
\hline Neoromicia tenuipinnis & 0 & 0 & 0 & 0 & 0 & 0 & 0 & 0 & 2 & 0 & 0 & 0 & 0 & 0 & 2 \\
\hline Glauconycteris egeria & 0 & 1 & 0 & 0 & 0 & 0 & 0 & 0 & 0 & 0 & 0 & 0 & 0 & 0 & 1 \\
\hline Pipistrellus nanulus & 0 & 0 & 0 & 6 & 0 & 3 & 0 & 0 & 0 & 0 & 0 & 0 & 0 & 0 & 9 \\
\hline Total individual & 7 & 9 & 82 & 6 & 1 & 10 & 4 & 4 & 9 & 1 & 5 & 7 & 15 & 6 & 166 \\
\hline Total species & 1 & 3 & 1 & 1 & 1 & 5 & 3 & 1 & 6 & 1 & 2 & 2 & 1 & 1 & 14 \\
\hline $\begin{array}{l}\text { Effort for } 12 \\
\text { metres/night }\end{array}$ & 20.8 & 28.6 & 24.7 & 28.6 & 14.3 & 14.3 & 14.3 & 14.3 & 14.3 & 14.3 & 14.3 & 14.3 & 14.3 & 7.8 & 239.2 \\
\hline capture success /night & 0.33 & 0.31 & 3.32 & 0.21 & $\mathbf{0 . 0 7}$ & 0.7 & 0.28 & 0.28 & 0.63 & 0.07 & 0.35 & 0.49 & 0.07 & 1.3 & 0.69 \\
\hline
\end{tabular}

Table 2. Sampling effort, capture success, and specific abundance of bats in the Mpem and Djim National Park, Cameroon.

to note that $M$. pusillus was recorded in the forest, savannah, and ecotone zones of the park. This is similar to the results of Fahr (1996) in Ivory Coast who recorded $69 \%$ of this species at the savannah, $18 \%$ at the ecotone, and $12 \%$ at the forest. E. franqueti, M. torquata, $R$. aegyptiacus, $H$. ruber, $H$. fuliginosus, $N$. tenuipinnis, and $P$. nanulus are found in the tropical forest and the humid savannah. This is in agreement with the works of Napoko et al. (2015) at Burkina Faso who noted the presence of H. cyclops in the savannah and forest; Fahr (1996) who sampled $70 \%$ of the individuals of $H$. ruber in the forest and $30 \%$ in the savanna; Bates et al. (2014) who recorded $N$. tenuipinnis in the two ecosystems in Congo. However, Haiduk et al. (1981) signaled the presence of L. angolensis in Adamawa confirming the presence of the species in both ecosystems in Cameroon. C. argynnis, Rhinolophus alcyone, $H$. fuliginosus, and G. egeria were uniquely in the forest zones. These species are few in number in Cameroon and are found in the Southern part of the country. Casinycteris argynnis is a solitary and rare species (Happold \& Happold, 2013) and only a single individual was captured at the park. A closely related species, C. campomaanensis, was discovered in the locality of CampoMa'an in the South of the country (Hassanin, 2014). Only two records of G. egeria were previously known in the South West region of Cameroon (forest zone). The works of Decher et al. (2016) signal the presence of $H$. fuliginosus in the Mountainous chains of Simandou in Guinea.

\section{CONCLUSIONS}

The Mpem and Djim National Park is one of the hotspots for biodiversity conservation in Cameroon. A significant portion of this ecosystem needs greater attention and we recommend the following actions: 
biodiversity surveys should be extended in this protected area in order to understand bats ecological requirements and threats, which help in setting up management plans adapted regionally and that allow a targeted use of resources; more targeted surveys and in-depth studies of species listed as endangered or critically endangered according to the International Red List should be carried out; deforestation by a combination of ground assessments and remote sensing should be monitored; bat habitat requirements need to be monitored on a long term basis and legal protection of bats roost and habitats at the park and its surroundings should be included in the management of wildlife species; long streams provide foraging and drinking habitats for bats at the park, and so, creation of bridges with vertical crevices can

\begin{tabular}{|c|c|c|c|c|c|c|c|}
\hline Sexes & Lb (mm) & Lf $(\mathbf{m m})$ & Lt (mm) & Le (mm) & Ltr (mm) & Lta $(\mathbf{m m})$ & Weight (g) \\
\hline \multicolumn{8}{|c|}{ Casinycteris argynnis } \\
\hline Female & $72(n=1)$ & 63 & 25 & 20 & 0 & 0 & 11 \\
\hline \multicolumn{8}{|c|}{ Epomops franqueti } \\
\hline Male & $\begin{array}{c}(92-130) \\
(\mathrm{n}=3)\end{array}$ & $(100-82)$ & $(33-38)$ & $(20-25)$ & 0 & 0 & $(73-131)$ \\
\hline Female & $\begin{array}{c}(93-104) \\
(n=3)\end{array}$ & $(85-97)$ & $(33-39)$ & $(20-24)$ & 0 & 0 & $(86-109)$ \\
\hline \multicolumn{8}{|c|}{ Micropteropus pusillus } \\
\hline Male & $\begin{array}{c}(50-63) \\
(n=10)\end{array}$ & $(42-52)$ & $(18-22)$ & $(13-15)$ & 0 & 0 & $(15-29)$ \\
\hline Female & $(41-68)(n=1)$ & $46-59$ & $16-23$ & $(11-16)$ & 0 & 0 & $(16-32)$ \\
\hline \multicolumn{8}{|c|}{ Myonycteris angolensis } \\
\hline Male & $76(n=1)$ & 82 & 35 & 18 & 0 & 16 & 66 \\
\hline Female & $85(n=1)$ & 82 & 32 & 18 & 0 & 15 & 76 \\
\hline \multicolumn{8}{|c|}{ Myonycteris torquata } \\
\hline Female & $71(n=1)$ & 57 & 31 & 13 & 0 & 12 & 22 \\
\hline \multicolumn{8}{|c|}{ Roussettus aegyptiacus } \\
\hline Male & $\begin{array}{c}108-110 \\
(n=3)\end{array}$ & $98-99$ & $40-42$ & $16-19$ & 0 & $(0.8-12)$ & $134-146$ \\
\hline Female & $\begin{array}{c}105-120 \\
(n=5)\end{array}$ & $98-102$ & $40-45$ & $19-22$ & 0 & $15-16$ & $134-148$ \\
\hline \multicolumn{8}{|c|}{ Rhinolophus alcyone } \\
\hline Female & $55(\mathrm{n}=1$ & 53 & 24 & 19 & 0 & 22 & 15 \\
\hline \multicolumn{8}{|c|}{ Hipposideros cyclops } \\
\hline Male & $(64-66)(n=2)$ & $(69-70)$ & $(32-35)$ & $(22-28)$ & 0 & $(26-32)$ & $(28-40)$ \\
\hline Female & $70(n=1)$ & 66 & 34 & 25 & 0 & 25 & 30 \\
\hline \multicolumn{8}{|c|}{ Hipposideros ruber } \\
\hline Male & $\begin{array}{c}(45-55) \\
(n=44)\end{array}$ & $(50-60)$ & $(19-24)$ & $(09-17)$ & 0 & $(19-32)$ & $(10-17)$ \\
\hline Female & $(42-55)(n=53$ & $(50-60)$ & $(19-24)$ & $(10-17)$ & 0 & $(22-32)$ & $(0.8-14)$ \\
\hline \multicolumn{8}{|c|}{ Hipposideros fuliginosus } \\
\hline Male & $(39-44)(n=8)$ & $(50-52)$ & $(20-24)$ & $(10-15)$ & 0 & $(30-35)$ & $(0.9-24)$ \\
\hline Female & $(40-47)(n=9)$ & $(50-52)$ & $(21-23)$ & $(11-14)$ & 0 & $(30-33)$ & $(0.8-10)$ \\
\hline \multicolumn{8}{|c|}{ Nycteris grandis } \\
\hline Male & $58(n=1)$ & 62 & 34 & 33 & 0 & 70 & 24 \\
\hline \multicolumn{8}{|c|}{ Neoromicia tenuipinnis } \\
\hline Male & $(32-34)(n=2)$ & $(30-31)$ & $(10-11)$ & $(0.7-10)$ & 0 & $(25-27)$ & $(0.2-0.5)$ \\
\hline \multicolumn{8}{|c|}{ Glauconycteris egeria } \\
\hline Male & $39(n=1)$ & 38 & 18 & 12 & 5 & 32 & 6 \\
\hline \multicolumn{8}{|c|}{ Pipistrellus nanulus } \\
\hline Male & $(25-35)(n=4)$ & $(26-30)$ & $(0.9-19)$ & $(0.7-0.9)$ & 0 & $(11-30)$ & $(0.2-0.3)$ \\
\hline
\end{tabular}

Table 3. Measurements of the different parameters of the species caught in the park. Lb: total body length, Lf: length of forearm, Lt: length of tibia, Ltr: length of tragus, Lta: length of tail, Le: length of ear, n: number of individual. 


\begin{tabular}{|c|c|c|c|c|c|c|c|c|c|c|c|}
\hline Localities & atitude & longitude & Localities & Latitude & longitude & Localities & \begin{tabular}{|l|} 
Latitude \\
\end{tabular} & longitude & localities & Latitude & longitude \\
\hline Aboulou & 2.3 & 12.05 & Dokoa & 36667 & 11.73333 & Lomié & 3.16667 & E13.61667 & \begin{tabular}{|l|} 
Nanga \\
Eboko \\
\end{tabular} & 4.68333 & 12.36667 \\
\hline Akak & 8333 & 6667 & ouala & 5528 & 9.94472 & beta & 8854 & 9.28936 & Ndiang & 7697 & 8719 \\
\hline Akon & 9 & 6448 & olowa & 3. & 11.9 & & 3.5 & E10.6 & dikinimeki & 76667 & 83333 \\
\hline Amban & 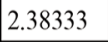 & .28333 & dea & 3.8 & 10.13333 & Mamfe & 5.754 & E9.3123 & Ndjole & 4.81667 & 11.93333 \\
\hline Atolo & 2548 & 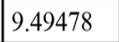 & fulen & 2.76667 & 10.71667 & ouba & 4.9522 & E9.8678 & Ngam & 3.76667 & 12.58333 \\
\hline Ayos & 8333 & .28333 & kona & 5.0288 & 9.4924 & Mang & 5.45681 & 10.30582 & Ngaoundere & 5.26667 & 14.01667 \\
\hline Bafut & 5.89649 & 20066 & cundu & 4.6884 & 8.96506 & Mang & 4.2456 & 9.4344 & \begin{tabular}{|l|} 
Ngobilo \\
\end{tabular} & 4.33333 & 10.61667 \\
\hline Bame & 5.95971 & 10.14597 & Eseka & 3.65 & 10.76667 & $M$ & 6.46667 & E11.55 & Ngoume & 48333 & 11.4 \\
\hline Banyo & 4.48333 & 14.01667 & Eshobi & 5.78583 & 9.36027 & Mbakaou & 6.31667 & E12.81667 & Njombo & 4.58056 & 9.66472 \\
\hline Batanga & 4.16667 & 14.46667 & Foulassi & 2.98333 & 11.96667 & Mbalmayo & 3.72361 & E9.955 & Nkoulou & 3.78333 & 11.56667 \\
\hline Batouri & 4.43333 & 14.36667 & Galim & 5.68955 & 10.3672 & mbouda & 5.62611 & E10.25421 & Ntui & 4.45 & 11.63333 \\
\hline Belabo & 4.93333 & 3 & aroua & 10.2281 & 14.81743 & Meanja & 4.265000 & 9.396700 & Obala & 4.16667 & 11.53333 \\
\hline Bele & 47917 & .79679 & enau & 240500 & 8.991200 & $M$ & 96667 & 11.96667 & Olounou & 36667 & 12.08333 \\
\hline Berto & 7.03879 & 15.00753 & Ikiliwindi & 4.7317 & 9.4881 & Meiganga & 6.51667 & 14.3 & \begin{tabular}{|l} 
petit \\
Batanga \\
\end{tabular} & 3.19861 & 9.92667 \\
\hline Besongabang & 5.70735 & 29875 & Isobi & 4.12068 & 8.99244 & Mengueme & 3.25000 & 11.400000 & Sakbayeme & 4.03333 & 10.56667 \\
\hline Bibundi & 4.2191 & 8.9876 & \begin{tabular}{|l} 
Isongo \\
\end{tabular} & 4.0687 & 9.0164 & Metet & 2.18333 & 11.33333 & Sangmelima & \begin{tabular}{|l|}
2.933333 \\
\end{tabular} & 11.983333 \\
\hline Bimbia & .95444 & 9.245 & Itoki & 3003 & 8.94229 & $\mathrm{M}$ & 2.83333 & 11.01667 & Somalomo & 3.38333 & 12.73333 \\
\hline Bipindi & 5.08333 & 10.41667 & Kita & 4.6861 & 9.0324 & Mieri & 4.25 & 13.98333 & Soppo & 4.1517 & 9.2514 \\
\hline Bityé & 3.01667 & 12.36667 & Klein & 3.19861 & 9.92667 & Mokolo & 10.74244 & 13.80227 & Tibati & 6.46504 & 12.62843 \\
\hline Bokwango & 4.1349 & 9.222 & Kombe & 4.08333 & E10.96667 & Moliko & 4.1529 & 9.285 & Tiko & 4.0745 & 9.3699 \\
\hline Bota & 4.0197 & 9.1956 & . & 70311 & E10.66639 & ngo & 4.5 & 9.83333 & Tinta & 2722 & 9.511 \\
\hline . & .52173 & $13.9^{\circ}$ & Koutaba & 5.685403 & 0337 & \begin{tabular}{|l} 
Mont \\
Camer \\
\end{tabular} & 216503 & 9.213773 & Tisongo & 3.568056 & 9.876111 \\
\hline Buea & 1527 & 9.241 & Koza & 10.86846 & E13.88205 & \begin{tabular}{|l|} 
Mont \\
Kupe
\end{tabular} & 801400 & 9.708100 & Tombel & 4.7466 & 9.6705 \\
\hline Campo & 2.36667 & 9.81667 & Kribi & 2.95 & E9.9 & Mpund & 4.2356 & 9.4108 & Touroua & 88333 & 12.96667 \\
\hline Debundscha & 4.1007 & 8.9786 & Kumba & 4.6921 & E9.2097 & Muea & 4.1749 & 9.3044 & Victoria & 4.0242 & 9.2149 \\
\hline Dimako & 4.38333 & 13.56667 & Lolabe & 2.66667 & E9.85 & Mukonje & 4.5776 & 9.5067 & Wakwa & 7.23333 & 13.58333 \\
\hline Dja & 5.30718 & 10.46168 & lolodorf & 3.23333 & E10.73333 & Mukono & 4.6283 & 9.1658 & Yagoua & 10.34107 & 15.23288 \\
\hline Djohong & 6.83333 & 14.7 & Lombe & 3.63389 & E9.98611 & Muyuka & 4.7251 & 9.6342 & Yaounde & 3.866667 & 11.516667 \\
\hline \multicolumn{12}{|c|}{$\mathbf{Y}$} \\
\hline
\end{tabular}

Table 4. Gazetteer of localities listed in the text.

provide ideal roosting sites when they spun such waters; access to vulnerable caves in the park and its surroundings should be restricted. Furthermore, it is important to create and maintain ponds for managing bats and other wildlife across the Mpem and Djim National Park Forest landscape.

\section{ACKNOWLEDGMENTS}

We express our gratitude to IDEA WILD for providing field equipment and to African Chiroptera Database for providing data on the distribution of bat species in Cameroon. We also thank the director of the Mpem and Djim National Bisseck Jean Marie and the Ministry of Forest and Fauna for the research permit.

\section{REFERENCES}

Aaron M.M., 2012. The characterization of echolocation signals of insectivorus bats in the far north region of Cameroon. Master Thesis, University of Maroua, 87 pp.

Aellen V., 1952. Contribution à l'étude des chiroptères du Cameroun. Mémoire de la Société Neuchâteloise des Sciences Naturelles, 8: 1-121. 
ACR, 2017. African Chiroptera Report 2017. AfricanBats NPC, Pretoria, $7380 \mathrm{pp}$.

Allen G.M., 1921. A new horseshoe bat from West Africa. Revue de Zoologie et de Botanique Africaines, 9: 193-196.

Andersen K., 1912. Catalogue of the Chiroptera in the British Museum. Second edition. Volume I: Megachiroptera. Trustees of the British Museum (Natural History), London: 1-854.

Bakwo Fils E.M., 2009a. Inventaire des chauves-souris de la réserve de biosphère du Dja, Cameroun. Le Véspère, 2: 11-20.

Bakwo Fils E.M., 2009b. La communauté de chauvessouris de la réserve de biosphère du Dja. Canopée, 28: 6-8.

Bakwo Fils E.M., 2010. The Bats of Cameroon: proving the benefits of the forgoten fruit bats. Bats, 28: 1113.

Bakwo Fils E.M. \& Kaleme P., 2016a. Micropteropus pusillus. The IUCN Red List of Threatened Species 2016: e.T13402A22126384. http://dx.doi.org/10. 2305/IUCN.UK.2016-1.RLTS.T13402A22126 384.en.

Bakwo Fils E.M. \& Kaleme P., 2016b. Myonycteris torquata. The IUCN Red List of Threatened Species 2016: e.T84463104A22046504. http://dx.doi.org/10. 2305 /IUCN.UK. 2016 - 1.RLT S.T 8446310 4A22046504.en.

Bakwo Fils E.M., Bol A. Anong D., Badoana T.D., Guieké B., Tsala D.E. \& Kuate F.A., 2014. Diversity of bats of the Far North Region of Cameroon with two first records for the country. Biodiversity, 15: 16-22.

Bannet-Garcia N., 2003. La protection des chauvessouris: ses enjeux ecologiques et sanitaires. Mémoire pour l'obtention du Diplôme de Médecine Agricole. Institut national de médecine agricole, $76 \mathrm{pp}$.

Bates Paul J.J., Kenneth C., Malcolmj P. \& Benjamin H., 2014. A review of the bats (Chiroptera) of the Republic of Congo, including eight species new to the country. Acta Chiropterologica, 15: 313-340, 2013 PL ISSN 1508-1109 C Museum and Institute of Zoology PAS doi: 10.3161/150811013X678955

Bergmans W., 1988. Taxonomy and biogeography of African fruit bats (Mammalia, Megachiroptera). 1. General introduction; material and methods; results: the genus Epomophorus Bennett, 1836. Beaufortia, 38: 75-146.

Bergmans W., 1990. Taxonomy and biogeography of African fruit bats (Mammalia, Megachiroptera). 3. The genera Scotonycteris Matschie, 1894, Casinycteris Thomas, 1910, Pteropus Brisson, 1762, and Eidolon Rafinesque, 1815. Beaufortia, 40, 111-177.

Bergmans W., Hutson A.M., Mickleburgh S. \& Monadjem A., 2017. Lissonycteris angolensis. The IUCN Red List of Threatened Species 2017: e.T44698A
22073874. http://dx.doi.org/10.2305/IUCN.UK.20 17-2.RLTS.T44698A22073874.en

Bikie H., Ndoye O. \& Sunderlin W.D., 2000. L'impact de la Crise économique sur les systèmes agricoles et le changement du couvert forestier dans la zone forestière humide du Cameroun. Center for International Forestry Research.Occasional. Paper n ${ }^{\circ}$ 27, 21 pp.

Cosson J.F., 1995. Captures of Myonycteris torquata (Chiroptera: Pteropodidae) in forest canopy in south Cameroon. Biotropica, 27: 395-396.

Decher J.A., Schaer J., Ryanw N., Kadjo B., Astrin J., Monadjem A. \& Rainer H., 2016. Bat diversity in the Simandou Mountain Range of Guinea, with the description of a new white-winged vespertilionid. Acta Chiropterologica, 17: 255-282,

Dobson G.E., 1878. Catalogue of the Chiroptera of the collection of the British Museum. Trustees of the British Museum, London: i - xlii; 1-567.

Dubois F., 2005. La déforestation des forêts primaires dans le monde: états des lieux, risques connus, approches de solutions. Master en Sciences de l'Information et des Bibliothèques Option: "Réseaux d'information et document électronique". École Nationale Supérieure des Sciences de l'Information et des Bibliothèques, $74 \mathrm{pp}$.

Eisentraut M., 1942. Beitrag zur Oekologie Kameruner Chiropteren.Mitteilungen aus dem Zoologischen Museum in Berlin, 25: 245-273

Eisentraut M., 1964. La faune de chiroptères de Fernando Po. Mammalia, 28: 529-552.

Fahr J., 1996. Die Chiroptera der Elfenbeinküste (unter Berücksichtigung des westafrikanischen Raumes): Taxonomie, Habitatpräferenzen und Lebensgemeinschaften. Julius-Maximilians-Universität Würzburg: Diploma-Thesis, 204 pp.

Fahr J., Ebigbo M.E. \& Formenty P., 2002. Final report on the bats (Chiroptera) of Mount Sangbé-national Park, Côte d'Ivoire. Afrique nature, Abidjan, 32 pp.

FAO, 1997. State of the World's Forests. Rome: Food and Agriculture Organization of the United Nations.

Fittkan E.J., 1997. Structural, Function and Diversity of Central Amazonian Ecosystems. In Natural Resources and Development. Tubingen. Institute for Scientific Co-operation, 30-41 pp.

Haiduk M.W., Baker R.J., Robbins L.W. \& Schlitter D.A., 1981. Chromosomal evolution in African Megachiroptera: G- and C-band assessment of the magnitude of change in similar standard karyotypes. Cytogenetics and Cell Genetics, 29: 221-232.

Hayman R.W. \& Hill J.E., 1971. Order Chiroptera. In: J. Meester and H. W. Setzer (Eds.), The Mammals of Africa: An Identification Manual, pp. 1-73. Smithsonian Institution Press, Washington, D.C., USA, $480 \mathrm{pp}$. 
Happold M. \& Happold D.C.D., 2013. Mammals of Africa Volume IV: Hedgehogs, shrews and bats. Blooms -bury Publishing, London, 800 pp.

Hassanin A., 2014. Description of a new bat species of the tribe Scotonycterini (Chiroptera, Pteropodidae) from Southwestern Cameroon. Comptes Rendus Biologies, 337: 134-142. DOI: 10.1016/j.crvi.2013.12. 006

Hill J.E., 1968. Bats from Cameroon, with description of a new species of Pipistrellus Bonn. Zoologische Beiträge, 19, 43-48.

Hutterer R, Joger U. 1982. Kleinsäuger aus dem Hochland von Adamaoua, Kamerun. Bonn. Zoologische Beiträge, 33: 119-132.

Hutterer R., Dieterlen F. \& Nikolaus G., 1992. Small mammals from forest islands of eastern Nigeria and adjacent Cameroon, with systematical and biogeographical notes. Zoologische Beiträge, 43: 393-414.

Jacobs D., Cotterill F.P.D. \& Taylor P.J., 2008. Glauconycteris egeria. The IUCN Red List of Threatened Species 2008: e.T44793A10941900. http:// dx.doi.org/10.2305/IUCN.UK.2008.RLTS.T44793A 10941900.en.

Kityo R. \& Nalikka B., 2016. Epomops franqueti. The IUCN Red List of Threatened Species 2016: e. T7909A22116503. http://dx.doi.org/10.2305/ IUCN. UK.2016-1.RLTS.T7909A22116503.en.

Korine C., 2016. Rousettus aegyptiacus. The IUCN Red List of Threatened Species 2016: e.T29730A220 43105. http://dx.doi.org/10.2305/ IUCN.UK.20162.RLTS. T29730A22 043105.en.)

Lindan P.J., Bates S., Muscat J., Harrison N.M. \& Gillan, M., 1997. Ab initio simulation of molecular processes on oxide surfaces. Faraday Discussions, 106: 135154

Maisels F., Keming E., Kemei M. \& Toh C., 2001. The extirpation of large mammals and implications for montane forest conservation: The case of the KilumIjim Forest, North-west Province, Cameroon. Oryx, 35: 322-331.

Matchie P., 1891. Ueber einige Saugetire von Kamerun und dessen Hinterland. Arch.naturg, 57: 351-356.

Matschie P., 1895. Wissenschaftliche Forschungsresultate über Land und Leute unseres ostafrikanischen Schutzgebietes und der angrenzenden Lander. In Moibius K., Deutsch-Ost-Afrika. Band III. Die Tierwelt Ost-Afrikas und der Nachbargebieten. Dietrich Reimer-Berlin.

Matschie P., 1899. Die Fledermäuse des Berliner Museums für Naturkunde. 1. Lieferung. Die Megachiroptera des Berliner Museums für Naturkunde. Georg Reimer-Berlin, viii - 102 pp.

Mc Bee K., Schlitter D.A. \& Robbins R.L., 1987. Systematics of African bats of the genus Eptesicus (Mammalia: Vespertilionidae). 2. Karyotypes of
African species and their generic relationships. Annals of Carnegie Museum, 56: 213-222.

Monadjem A. \& Fahr J., 2017a. Neoromicia tenuipinnis. The IUCN Red List of Threatened Species 2017: e.T44926A22047067. http://dx.doi.org/10.2305/IUC N.UK.2017-2.RLTS.T44926A22047067.en

Monadjem A. \& Fahr J., 2017b. Pipistrellus nanulus. The IUCN Red List of Threatened Species 2017: e.T17353A22126587. http://dx.doi.org/10.2305/IUC N.UK.2017-2.RLTS.T17353A22126587.en.

Monadjem A., Taylor P.J., Jacobs D. \& Cotterill F., 2017a. Rhinolophus alcyone. The IUCN Red List of Threatened Species 2017: e.T19523A 21981963. http://dx.doi.org/10.2305/IUCN.UK.2017-2.RLTS. T19523A21981963.en.

Monadjem A., Juste J., Bergmans W., Mickleburgh S., Hutson A.M. \& Fahr J., 2017b. Hipposideros cyclops. The IUCN Red List of Threatened Species 2017: e. T10126A22095945. http://dx.doi.org/10.2305/IUCN. UK.2017-2.RLTS.T10126A2 2095945.en

Monadjem A., Juste J., Bergmans W., Mickleburgh S., Hutson A.M. \& Fahr J., 2017c. Hipposideros fuliginosus. The IUCN Red List of Threatened Species 2017: e.T10134A22090466. http://dx.doi.org/10. 2305/IUCN.UK.2017-2.RLTS.T10134 A22090466. en

Monadjem A., Fahr J., Hutson A.M., Mickleburgh S. \& Bergmans W., 2017d. Hipposideros ruber. The IUCN Red List of Threatened Species 2017: e.T10157A 22102440. http://dx.doi.org/10.2305/IUCN.UK.2017 -2.RLTS.T10157A22102440.en.

Monadjem A., Bergmans W., Mickleburgh S. \& Hutson A.M., 2017e. Nycteris grandis. The IUCN Red List of Threatened Species 2017: e.T14929A2 2012638. http://dx.doi.org/10.2305/IUCN.UK.2017-2.RLTS. T14929A22012638.en.

MINFOF, 2011. Inventaire dans le Parc de Mpem et Njim. Rapport d'activité, $171 \mathrm{pp}$.

Müller P., Nagel P. \& Flacke W., 1981. Ecological side effects of dieldrin application against tsetse flies in Adamaoua, Cameroon. Oecologia, 50: 187-194.

Napoko M.K., Adama O., Laurent G., Adjima T., Wendengoudi G. \& Fahr J., 2015. Diversity and distribution of bats (Mammalia Chiroptera) in Burkina Faso. Biodiversity Journal, 6: 597-632

Ndoye O. \& Kaimowitz D., 1998. Macro-economics, markets, and the humid forests of Cameroon, 19671997. Journal of Modern African Studies, 38: 225253.

Patterson B.D. \& Webala P.W., 2012. Keys to East African Bats. Fieldiana: Life and Earth Sciences (Museum of Natural History), $60 \mathrm{pp}$.

Perret J.L. \& Aellen V., 1956. Mammifères du Cameroun de la collection J. L. Perret. Revue suisse de zoologie, 63: $395-450$. 
Peters W.C.H., 1876. Ueber die von dem verstorbenen Professor Dr. Reinhold Buchholz in Westafrika gesammelten Säugethiere. Monatsberichte der königlichen preussische Akademie für Wissenschaften, Berlin, 469-485.

Reis R.D.N. \& Guillaumet J.L., 1983. Les chauves-souris frugivores de la région de Manaus et leur rôle dans la dissémination des espèces végétales. Revue d'Écologie - La Terre et la Vie, 38: 147-169.

Rosevear D.R., 1965. The Bats of West Africa. Trustees of the British Museum Natural History, London , 418 pp.

Sanborn C.C., 1936. Descriptions and records of African bats. Field Museum of Natural History. Zoological series, 20: 107-114.

Sanderson I.T., 1940. The mammals of the North Cameroons Forest Area. Being the results of the Percy Sladen Expedition to the Mamfe Division of the British Cameroons. Transactions of the Zoological Society of London, 24: 623-725.
Santoir C. \& Bodba A., 1995. Atlas régional Sud-Cameroun. Office de la Recherche Scientifique et Technique Outre-mer, Paris, 53 pp.

Sjöstedt Y., 1897a. Säugetiere aus Kamerun, WestAfrika. Bihang Till Kungl Svenska vetenskapsakademiens handlingar, 423: 1-50.

Sjöstedt Y., 1897b. Die Säugethiere des nordwestlichen Kamerungebietes. Kungl. Svenska vetenskapsakademiens handlingar, 10: $22 \mathrm{pp}$.

Van C.V. \& Happold M., 2013. Pipistrellus nannulus Tiny Pipistrelle (Temminck's Leaf-nosed Bat). The mammals of Africa, Volume IV, London, 800 pp.

Verbelen F., 1999. L'exploitation abusive des forets équatoriales du Cameroun. 49 pp.

Webala P., Kityo R. \& Betty N., 2016. Casinycteris argynnis. The IUCN Red List of Threatened Species 2016: e.T3999A22127399. http://dx.doi.org/10. 2305/IUCN.UK.2016-1.RLTS.T3999A22127399. en. 